\title{
Pengaruh Penambahan Serat Cangkang Kelapa Sawit (Palm Kernel Fiber) Terhadap Sifat Mekanik Dan Stabilitas Termal Komposit Epoksi/Serat Cangkang Kelapa Sawit
}

\author{
Olga Leonev Vasdazara, Hosta Ardhyananta, Sigit Tri Wicaksono \\ Teknik Material, Fakultas Teknologi Industri, Institut Teknologi Sepuluh Nopember (ITS) \\ e-mail:Hostaa@mat-eng.its.ac.id
}

\begin{abstract}
Abstrak-Epoksi adalah jenis polimer termoseting dengan kekuatan tarik, stabilitas termal yang tinggi dibandingkan jenis polimer lainnya. Tetapi pada aplikasi yang dibutuhkan sifat fleksibilitas tinggi, epoksi menunjukkan performa yang rendah. Maka dibutuhkan material tambahan berupa pengisi serat alam untuk meningkatkan sifat mekanik dan stabilitas termal dari epoksi. Penelitian ini dilakukan untuk mengembangkan material Biopolimer dan memiliki sifat mekanik, dan stabilitas termal yang baik pada aplikasi Papan Partikel. Produk polimer ini menggunakan bahan dasar Epoksi dengan variasi pengisi Serat Cangkang Sawit. Pengujian yang dilakukan yaitu uji Morfologi SEM, Uji FTIR, Uji Kekerasan Shore D, Uji kekuatan tarik, dan Uji TGA. Pengujian kekerasan menunjukkan peningkatan nilai kekerasan dengan variasi pengisi Serat Cangkang Sawit 20, 40, 60\% dengan nilai tertinggi pada variasi Cangkang Kelapa Sawit 60\% sebesar 79 HD. Pengujian kekuatan tarik menunjukkan penurunan dengan variasi pengisi serat cangkang sawit 20, 40, 60\% dengan nilai 29,6 MPa, 23,19 MPa, dan 24,45 MPa. Pengujian stabilitas temperatur menunjukkan peningkatan dengan variasi pengisi serat cangkang sawit 20, 40, dan $60 \%$. Stabilitas temperatur tertinggi terdapat pada variasi pengisi serat cangkang sawit $20 \%$ dengan $T_{5} 360{ }^{\circ} \mathrm{C}$. Berdasarkan hasil tersebut terdapat pengaruh penambahan serat cangkang sawit terhadap sifat mekanik dan stabilitas termal untuk resin epoksi pada aplikasi papan partikel.
\end{abstract}

Kata Kunci-Epoksi, Pengisi, Sifat Mekanik, Stabilitas Termal.

\section{PENDAHULUAN}

$\mathrm{P}$ ADA zaman sekarang penggunaan dan pengaplikasian kayu solid dan komposit serbuk kayu sebagai bahan utama dalam building material sudah cukup populer dan juga menjadi pilihan utama masyarakat di Indonesia, namun dari bahanbahan tersebut mempunyai kelemahan tersendiri yaitu jumlah ketersediaan dan meningkatnya harga limbah serbuk kayu dan kayu solid di Nusantara ini.

Kelapa Sawit merupakan tanaman Monokotil sehingga tanaman ini tidak memiliki kambium. Pertumbuhannya yang cepat dan dapat dipanen pada umur sekitar 3 tahun. Potensi perkebunan kelapa sawit di Indonesia pada tahun 1995 - 2005 luas arealnya bertambah dari 2,7 juta ha sampai 4,5 juta ha. Apabila setiap $10 \%$ dari tanaman sawit ini diremajakan, maka dihasilkan limbah kelapa sawit 11,7 juta pohon/tahun setara dengan 5,85 juta ton pertahun (Prayitno dan Darnoko, 1994). Cangkang kelapa sawit juga merupakan salah satu limbah yang jumlahnya mencapai $60 \%$ dari produksi minyak inti.Limbah cangkang kelapa sawit berwarna hitam keabuan, bentuk tidak beraturan, dan memiliki kekerasan cukup tinggi. Cangkang sawit mengandung selulosa sebesar $45 \%$ dan hemiselulosa sebesar 26\% [1].

Epoxy memiliki sifat keras, kuat, bening, dan tahan terhadap panas. Penggunaan Serat alam dengan kombinasi campuran yang sesuai pada Matriks akan menghasilkan komposit yang lebih baik [2]. Peningkatan kekuatan mekanik komposit dapat dilakukan dengan variasi serat. Serat yang ditambahkan bisa berupa serat alam maupun buatan. Kekurangan dari komposit serat alam yaitu kurang baiknya ikatan antara matriks dan reinforce sehingga menghasilkan sifat komposit yang kurang baik, karena kebanyakan serat alam memiliki sifat Hidrofilik (meyerap air) sehingga air dapat masuk ke dalam ikatan komposit antara matriks dan reinforce. Penelitian ini mengkombinasikan serat Cangkang Kelapa sawit sebagai reinforce (penguat), Epoxy sebagai matriks, Poly Amino Amid sebagai Hardener terhadap sifat mekanik dan stabilitas thermal. Karena penggunaan Cangkang Kelapa Sawit untuk aplikasi Papan Partikel di Indonesia ini masih belum optimal. Kebanyakan orang menggunakan serbuk kayu dan kayu solid. Maka dari itu penelitian ini memilih serat Cangkang Kelapa Sawit bermatriks Epoxy untuk mengetahui sifat mekanik dan stabilitas thermal pada material komposit tersebut untuk aplikasi Papan Partikel.

\section{METODE PENELITIAN}

\section{A. Bahan Penelitian}

Bahan yang digunakan dalam penelitian ini antara lain Epoksi, Poli(Amino Amid) yang dibeli di PT. Justus Kimia Raya dan Serat Cangkang Kelapa Sawit. 


\section{B. Prosedur Penelitian}

Untuk menghasilkan hasil penelitian yang sesuai dengan harapan, maka penelitian ini memiliki beberapa tahap percobaan yang akan dilakukan hingga didapatkan hasil berupa komposit. Pertama, Mempersiapkan semua alat dan bahan. Kedua, Mengukur massa campuran matriks polimer dengan perbandingan komposisi massa (Epoksi / PAA) 60/40 dengan variasi pengisi Serat Cangkang Kelapa Sawit 0\%, 20\%, 40\%, dan $60 \%$ ukuran 20 mesh $(0,84 \mathrm{~mm})$. Ketiga, Mencampurkan matriks Epoksi dengan variasi pengisi dan diaduk menggunakan manual stirring selama 5 menit hingga homogen pada temperatur kamar. Keempat, Menuangkan hasil campuran ke dalam cetakan kayu untuk dijadikan spesimen sesuai pengujian. Kelima, Spesimen di-curing di ruangan pada temperatur kamar 5 jam, tanpa ada pemberian laju pemanasan. Keenam, Melakukan pengujian tarik, kekerasan, SEM, FTIR dan TGA terhadap spesimen.

\section{Pengujian Thermogravimetric Analysis (TGA)}

Pengujian dilakukan untuk mengetahui stabilitas termal dari hasil campuran polimer komposit. Pada prinsipnya metode ini mengukur berkurangnya massa material ketika dipanaskan dari temperatur kamar hingga temperatur tinggi. Alat TGA pada Gambar 3.5 dilengkapi dengan timbangan mikro di dalamnya sehingga secara otomatis berat sampel setiap saat bisa terekam dan ditampilkan dalam bentuk grafik. Pelaksanaan pengujian ini dilakukan dengan menempatkan sampel di atas meja putar yang ada di dalam mesin. Selanjutnya dilakukan pengisian data berat awal untuk masing - masing sampel ke dalam sistem komputer di mana berat maksimal $20 \mathrm{mg}$. Kondisi dalam mesin dialiri udara kering dari tabung gas dengan kecepatan pengaliran tertentu. Program pengoperasian mesin berupa kecepatan pemanasan, jarak temperatur, dan pendinginan dilakukan dengan melalui pemasukan data ke komputer. Analisa dilakukan dengan menaikkan temperatur secara bertahap dan analisa berat terhadap temperatur, sehingga didapatkan kurva hasil pengujian berupa fungsi temperatur terhadap berat sampel.

\section{Pengujian Kekerasan}

Pengujian ini digunakan untuk menganalisis tingkat kekerasan dari sampel polimer komposit epoksi menggunakan alat Durometer Shore D. Dimensi spesimen dan prosedur yang dilakukan menggunakan sumber acuan standar ASTM D2240 Durometer Hardness. Dimana ketebalan minimal sampel yaitu 6 $\mathrm{mm}$. Durometer ini bekerja mengukur ketahanan material terhadap penetrasi indentor seperti jarum berpegas. Skala yang digunakan pada pengujian ini adalah dalam nilai Shore D.

\section{E. Pengujian Kekuatan Tarik}

Uji tarik yang akan dilakukan pada praktikum ini sesuai dengan standar American Society for Testing Materials (ASTM) D638 tipe I, dengan menggunakan mesin Uji tarik dengan spesimen polimer rigid menggunakan standar ASTM D638 untuk menganalisa perilaku polimer dengan pembebanan hingga kekuatan tarik maksimum

\section{F. Pengujian Fourier Transform Infrared Spectroscopy (FTIR)}

FTIR merupakan instrument yang menggunakan prinsip spektroskopi. Spektroskopi adalah spektroskopi inframerah yang dilengkapi dengan transformasi fourier untuk deteksi dan analisis hasil spektrumnya [3].

Spektrum inframerah dihasilkan dari pentrasmisian cahaya yang melewati sampel, pengukuran intensitas cahaya dengan detektor dan dibandingkan dengan intensitas tanpa sampel sebagai fungsi panjang gelombang. Spektrum inframerah yang diperoleh kemudian diplot sebagai intensitas fungsi energi, panjang gelombang $(\mu \mathrm{m})$ atau bilangan gelombang $(\mathrm{cm}-1)$ [3].

Pengujian FTIR dilakukan untuk mengetahui informasi terkait ikatan kimia yang ada. Ikatan kimia tersebut diindikasikan dengan puncak-puncak yang berbeda. Spesimen yang digunakan untuk pengujian FTIR berupa cuplikan kecil dari material yang dibuat. Mesin uji FTIR yang digunakan adalah Nicolet IS10. Sampel diletakkan sample holder, kemudian detector didekatkan pada sampel. Pastikan sampel uji memiliki permukaan yang rata dan ketebalan yang sama.

\section{G. Pengujian Scanning Electron Microscope (SEM)}

Mesin SEM digunakan untuk mengetahui morfologi dan ukuran butir serat. Mesin SEM yang digunakan milik laboratorium di Jurusan Teknik Material dan Metalurgi FTI ITS. Adapun cara kerja dari SEM adalah electro gun memperoduksi electron beam, anoda menangkap electron beam untuk kemudia diarahkan ke sampel kemudian serangkaian lensa magnetik memfokuskan beam ini dan menembakkan ke sampel, scanner membaca struktur permukaan sampel selanjutnya menangkap sinyal dari secondary dan black scattered electron untuk dikirim ke sistem kontrol sehingga dapat dilihat gambarnya pada monitor dan dapat dicetak biala diperlukan.

\section{HASIL DAN PEMBAHASAN}

Penelitian ini menghasilkan campuran berupa polimer blend yaitu, Epoksi/PAA/Serat (60/40/0), Epoksi/PAA/Serat (48/32/20), Epoksi/PAA/Serat (36/24/40), dan Epoksi/PAA/Serat (24/16/60). Polimer blend yang dihasilkan kemudian dilakukan analisa untuk diketahui sifat mekaniknya.

\section{A. Pengaruh Pengisi Serat Cangkang Sawit terhadap Struktur Ikatan Epoksi dengan Analisa FTIR}

Melalui Uji FTIR dapat diketahui bahwa reaksi pencampuran epoksi dan curing agent mengkonsumsi energi dalam jumlah yang berbeda beda.Transmittance (\%) merupakan mewakili besarnya transmisi atau perpindahan energi efektif yang terjadi selama rekasi, Sedangkan Wavenumbers (Cm-1) mewakili panjang gelombang yang dihasilkan pada saat rekasi. Gelombang tersebut memiliki titik-titik puncak yang menandakan terjadinya hambatan transmisi energi efektif dan memiliki arti telah terjadi aktivitas transformasi ikatan.

Pada Gambar 1 menunjukan daerah puncak serapan sinar inframerah dari polimer komposit epoksi cangkang sawit. Daerah serapan sinar inframerah dengan garis spektrum berwarna merah merupakan material polimer komposit epoksi 
serat cangkang sawit 20\%. Pada puncak serapan $3340.86 \mathrm{~cm}^{-1}$ menunjukan ikatan $\mathrm{O}-\mathrm{H}$ yang mengalami peregangan. Kemudian terdapat ikatan $\mathrm{C}-\mathrm{H}$ yang mengalami peregangan pada puncak serapan $2919 \mathrm{~cm}^{-1}$, dan $2850,12 \mathrm{~cm}^{-1}$.

Fenomena tersebut menunjukan adanya gugus fungsi alkana $\left(\mathrm{CH}_{2}\right.$ atau $\left.\mathrm{CH}_{3}\right)$. Kemudian terdapat ikatan $\mathrm{C}=\mathrm{O}$ yang bergetar pada puncak serapan $2357,70 \mathrm{~cm}^{-1}$ dan $2341,52 \mathrm{~cm}^{-1}$ yang menunjukan gugus fungsi dari cincin aromatic atau aromatic homocyclic. Pada puncak serapan 1734,74 $\mathrm{cm}^{-1}$ menunjukan ikatan $\mathrm{C}=\mathrm{C}$ yang mengalami deformasi yang merupakan gugus fungsi alkena. Pada puncak serapan 1507,66 $\mathrm{cm}^{-1}$ terdapat ikatan C-C yang mengalami deformasi yang menunjukan adanya gugus fungsi cincin aromatic. Pada puncak serapan $1032,59 \mathrm{~cm}^{-1}$ terdapat ikatan C-O-C yang mengalami peregangan merupakan gugugs fungsi dari eter aromatik. Kemudian terjadi peregangan ikatan C-O pada puncak serapan $826 \mathrm{~cm}^{-1}$ yang menunjukan gugus fungsi oxirane. Pada puncak serapan $769,72 \mathrm{~cm}^{-1}$ ikatan O-H mengalami deformasi yang merupakan gugus fungsi alkena. Pada puncak 668,42 $\mathrm{cm}^{-1}$ menunjukan ikatan $\mathrm{C}-\mathrm{H}$ yang mengalami deformasi yang menunjukan adanya cincin aromatik.

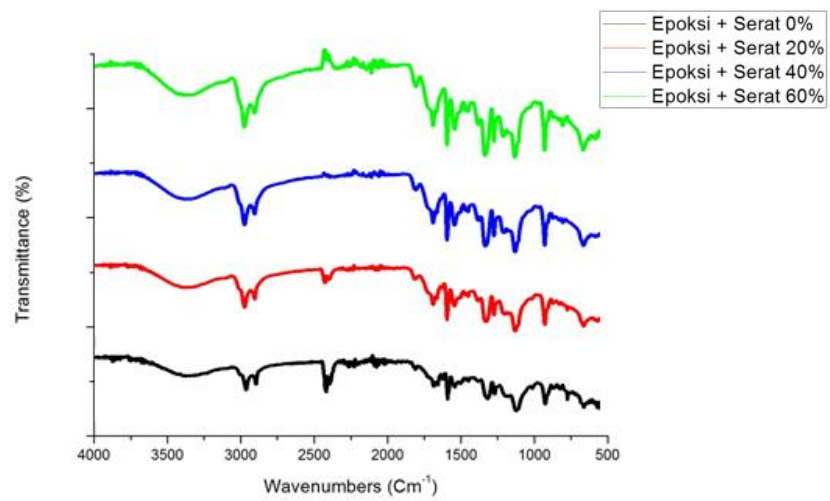

Gambar 1. Struktur FTIR Polimer Komposit Epoksi Cangkang Sawit

Tabel 1 menunjukkan gugus fungsi dari campuran epoksi dengan Serat Cangkang Kelapa Sawit. Pada hasil pengujian spektrum FTIR terlihat bahwa dengan penambahan komposisi Serat Cangkang Kelapa Sawit mengakibatkan pemutusan ikatan $\mathrm{O}-\mathrm{H}$ dan $\mathrm{C}=\mathrm{C}$. Hal ini dapat dilihat dari penurunan peak gugus fungsi tersebut seiring dengan penambahan komposisi Serat Cangkang Kelapa Sawit. Pemutusan gugus fungsi tersebut diasumsikan karena ikatan $\mathrm{O}-\mathrm{H}$ dan $\mathrm{C}=\mathrm{C}$ pada epoksi berikatan kimia dengan Serat Cangkang Kelapa Sawit yang kemudian membuat ikatan dan network baru seperti yang terlihat pada Tabel 1. Pemutusan ikatan ini terjadi ketika pencampuran matriks. Sehingga reaksi kimia banyak terjadi pada campuran matriks. Pada ikatan yang terjadi pada uji FTIR membuktikan bahwa campuran yang terjadi adalah campuran epoksi $\left(\mathrm{C}_{2} \mathrm{H}_{3} \mathrm{O}-\right)$ yang ditandai dengan adanya ikatan C-H dan C-O-C.

B. Analisa Morfologi Pengujian SEM (Scanning Electron Microscope) Material Polimer Komposit Epoksi

Pengujian SEM dilakukan menggunakan menggunakan mesin FEI INSPECT S50 dengan tegangan $10.000 \mathrm{kV}$ dengan hamburan elektron dalam membentuk bayangan pada daerah penampang melintang (cross section) polimer komposit epoksi Tabel 1.

Puncak Serapan, Ikatan Kimia, dan Gugus Fungsi Epoksi

\begin{tabular}{cc}
\hline Gelombang & Ikatan \\
\hline 3340.86 & O-H and stretching \\
2919 & C-H stretching(alkana) \\
1734.74 & C=C stretching(lignin) \\
1507.66 & C-C stretching \\
1032.59 & C-O-C stretching \\
826 & C-O stretching(Cellulose; hemi-cellulose; lignin) \\
769,72 & O-H deformation \\
668.42 & C-H deformation \\
\hline
\end{tabular}

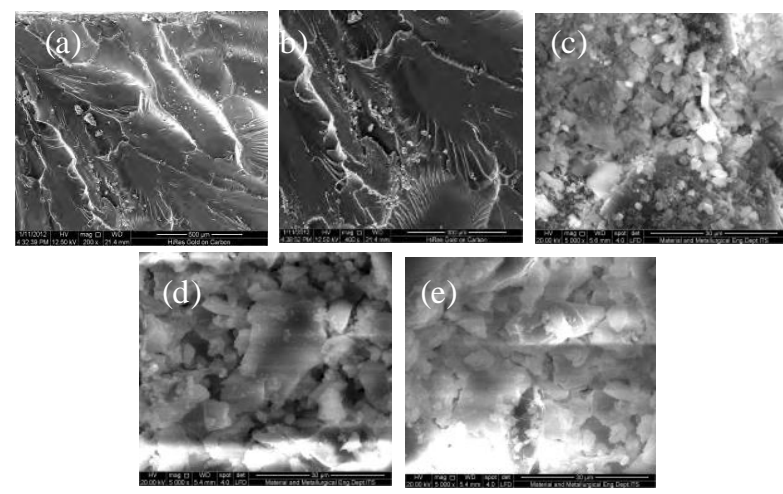

Gambar 2. Mikrograf SEM Polimer Komposit Epoksi Sereat Cangkang Sawit, (a) Hasil SEM E/S 0\% perbesaran 200X, (b) Hasil SEM E/S 0\% perbesaran 400X, (c) Hasil SEM E/S 20\% perbesaran 5000X, (d) Hasil SEM E/S 40\% perbesaran 5000X, (e)Hasil SEM E/S 60\% perbesaran $5000 \mathrm{X}$

Pada Gambar 2 Gambar (a) dan (b) diatas menunjukkan hasil patahan E/S(0\%). Terlihat bahwa pola patahan yang dihasilkan adalah patahan getas, dikarenakan halusnya penampang permukaan. Ini juga mempunyai korelasi dengan hasil uji tarik yang mana pada komposisi ini mempunyai UTS yang tinggi, sehingga sifat getasnya juga lebih tinggi dari yang lain.

Gambar (c) menunjukan morfologi cross sectional are dari polimer komposit epoksi serat cangkang sawit 20\%. Terlihat pengaruh ikatan Serat Cangkang Sawit terhadap epoksi yang terlihat menggumpal dan berikatan dengan epoksi secara halus dan rapat. Gambar (d) morfologi cross sectional area dari polimer komposit epoksi cangkang sawit $40 \%$ menunjukan tekstur yang hampir sama dengan polimer komposit cangkang sawit 20\%, namun terlihat lebih kasar dan tidak berikatan secara rapat, sehingga memberikan pengaruh terhadap turunnya sifat kekuatan tarik dari Polimer komposit cangkang sawit. Gambar (e) menunjukan morfologi cross sectional are dari polimer komposit epoksi serat cangkang sawit $60 \%$. Terlihat bahwa pengaruh ikatan serat cangkang sawit terhadap epoksi tidak begitu rapat dan merata, hampir sama dengan gambar (d), akan tetapi gambar (e) lebih terlihat rapat jika dibandingkan dengan gambar (d). 


\section{Pengaruh Pengisi Material Serat Alam terhadap Sifat Kekerasan Epoksi}

Pengujian kekerasan material Serat Alam epoksi dilakukan dengan menggunakan alat durometer shore $\mathrm{D}$ dengan standard pengujian ASTM D2240 dengan indentor baja berbentuk tabung silinder. Pengujian dilakukan pada 3 titik indentasi pada setiap spesimen, kemudian diambil nilai rata - rata dari hasil indentasi tersebut.

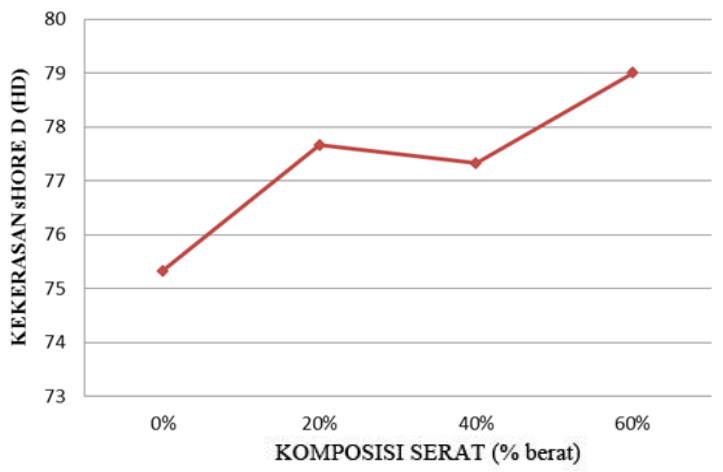

Gambar 3. Pengaruh Pengisi Serat Cangkang Sawit terhadap Kekerasan Polimer Komposit Epoksi

Hasil pengujian kekerasan Material polimer komposit epoksi ditunjukan pada Gambar 3. Material epoksi murni yang ditunjukan pada grafik memiliki rata-rata nilai kekerasan sebesar 75,33 HD. Kemudian, Material polimer komposit epoksi berpengisi serat alam 20\% yang ditunjukan dengan grafik memiliki rata-rata nilai kekerasan sebesar 77,66 HD. Material Polimer komposit epoksi berpengisi serat alam $40 \%$ yang ditunjukan dengan grafik memiliki rata-rata nilai kekerasan sebesar 77,33 HD. Kemudian, Material polimer komposit epoksi berpengisi serat alam 60\% yang ditunjukan dengan grafik memiliki rata-rata nilai kekeras an sebes ar $79 \mathrm{HD}$.

Berdasarkan pengujian kekerasan yang telah dilakukan, Variasi material Polimer Komposit Epoksi serat alam 40\% dan $60 \%$ memiliki kemampuan meningkatkan sifat kekerasan epoksi. Sedangkan material polimer komposit serat alam 0\% dan $40 \%$ memiliki pengaruh turunnya nilai kekerasan dari epoksi. Sifat kekerasan pada material meningkat dengan bertambahnya variasi serat. Sifat kekerasan material polimer komposit epoksi tertinggi yaitu material epoksi berpengisi serat cangkang sawit $20 \%$ dan 60\% dengan nilai kekerasan 77,66 HD dan 79 HD.

D. Pengaruh Pengisi Material Serat Alam terhadap Sifat Kekuatan Tarik Maksimum Terhadap Polimer Komposit Epoksi

Pengujian kekuatan tarik polimer epoksi dilakukan menggunakan mesin uji tarik dengan standard pengujian ASTM D 638 tipe I. Sampel yang diujikan memiliki ketebalan rata-rata $6 \mathrm{~mm}$, lebar rata-rata gage area $13 \mathrm{~mm}$, dan panjang total sampel rata-rata $165 \mathrm{~mm}$. Hasil pengujian kekuatan tarik ditunjukan pada Gambar 4.

Polimer komposit variasi pengisi $0 \%$ memiliki nilai kekuatan tarik sebesar 60,6 MPa. Kemudian material polimer berpengisi serat alam $20 \%$ pada grafik memiliki nilai kekuatan tarik sebesar 29,6 MPa. Material polimer komposit berpengisi serat alam $40 \%$ pada grafik memiliki nilai kekuatan tarik sebesar 23,19 MPa. Kemudian material polimer komposit epoksi berpengisi serat alam $60 \%$ pada grafik memiliki nilai kekuatan tarik sebesar 24,45 MPa. Menurut data SNI 03-2105-2006 kekuatan tarik minimum papan partikel adalah $3,1 \mathrm{kgf} / \mathrm{cm}^{2}$, Sedangkang kekuatan tarik dari penelitian ini adalah 29,6 $\mathrm{MPa}\left(301,83 \mathrm{kgf} / \mathrm{cm}^{2}\right)$. Berdasarkan pengujian yang telah dilakukan, material ini sesuai dengan standar SNI 03-2105-2006.

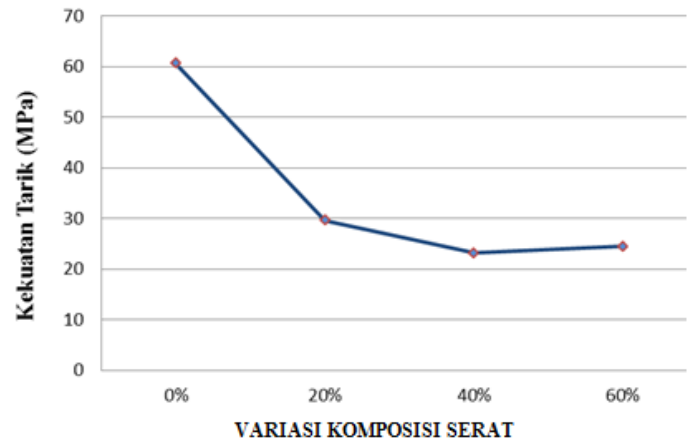

Gambar 4. Pengaruh Pengisi Serat Cangkang Sawit terhadap Kekuatan Tarik Polimer Komposit Epoksi

Semakin bertambah serat, maka sifat kekerasan dari material akan menurun. Seperti dijelaskan pada Gambar 4, seiring bretambahnya serat cangkang sawit maka kekuatan tarik dari material makin menurun. Kenaikan rata-rata kekuatan tensil karena adanya serat [4]. Serat yang tersebar memperngaruhi distribusi beban dan tegangan pada komposit. Namun, ratarata kekuatan tarik mulai menurun saat banyaknya kandungan serat melewati komposisi 10wt\% [5]. Nilai kekuatan tarik yang diperoleh dipengaruhi oleh tingkat dispersi serat. Selanju tnya, jumlah komposisi serat juga menyebabkan adanya retakan di dalam. Keretakan menyebabkan transfer tegangan yang tidak seragam karena adanya serat di epoxy serat kelapa sawit [4].

E. Pengaruh Variasi Serat Alam terhadap Kestabilan Termal Polimer Komposit Epoksi

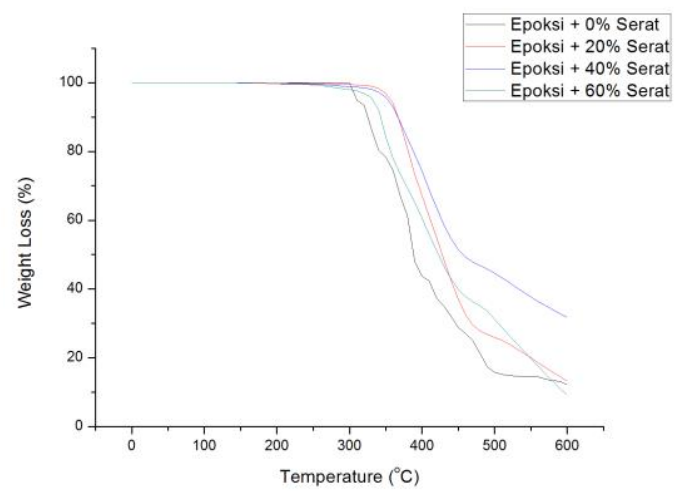

Gambar 5. Kurva Thermogravimetric Analysis (TGA) dari Variasi Komposisi Polimer Komposit Serat Cangkang Sawit

Gambar 5 menunjukan titik $\mathrm{T}_{5}$ dari variasi komposisi Polimer komposit epoksi cangkang sawit .Polimer Komposit Epoksi Serat Cangkang Kelapa Sawit 0\% mengalami penurunan massa 
$5 \%$ atau titik $\mathrm{T}_{5}$ pada temperatur $310{ }^{\circ} \mathrm{C}$. Polimer Komposit Epoksi Serat Cangkang Kelapa Sawit 20\% mengalami penurunan massa $5 \%$ atau titik $\mathrm{T}_{5}$ pada temperatur $360{ }^{\circ} \mathrm{C}$. Polimer Komposit Epoksi Serrat Cangkang Kelapa Sawit 40\% mengalami penurunan massa $5 \%$ atau $\mathrm{T}_{5}$ pada temperatur 350 ${ }^{\circ}$ C. Polimer Komposit Serat Cangkang Kelapa Sawit $60 \%$ mengalami $\mathrm{T}_{\text {maks }}$ pada temperatur $350{ }^{\circ} \mathrm{C}$.

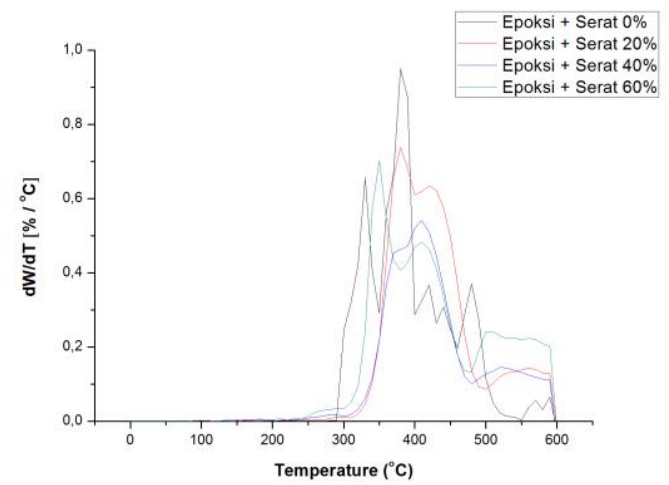

Gambar 6 Kurva Derivative Thermogravimetric (DTG) dari Variasi Komposisi Polimer Komposit Serat Cangkang Sawit.

Tabel 2.

Pengaruh Pengisi Serat Cangkang Kelapa Sawit terhadap Temperatur Dekomposisi $\mathrm{T}_{5}$ dan $\mathrm{T}_{\text {maks }}$ dari Polimer Epoksi.

\begin{tabular}{ccc}
\hline Material & $\mathrm{T}_{5}\left({ }^{\circ} \mathrm{C}\right)$ & $\mathrm{T}_{\text {maks. }}\left({ }^{\circ} \mathrm{C}\right)$ \\
\hline Epoksi/Serat $0 \%$ & 310.0 & 380.0 \\
Epoks i/Serat 20\% & 360.0 & 380.0 \\
Epoksi/Serat 40\% & 350.0 & 410.0 \\
Epoksi/Serat 60\% & 330.0 & 350.0 \\
\hline
\end{tabular}

Tabel 2 menunjukan variasi $\mathrm{T}_{5}$ dan $\mathrm{T}_{\text {maks }}$ dari variasi komposisi Serat Cangkang Kelapa Sawit. Variasi komposisi Serat Cangkang Sawit 20\%, Serat 40\%, dan Serat $60 \%$ meningkatkan kesetabilan temperatur dari Polimer Komposit Epoksi. Polimer Komposit Epoksi Serat Cangkang Kelapa Sawit memiliki kesetabilan temperatur tertinggi dengan $\mathrm{T}_{5} 360^{\circ} \mathrm{C}$.

Tahap pertama terjadinya dekomposisi terjadi pada temperatur berkisar $140-390^{\circ} \mathrm{C}$ yang merupakan fenomena penguapan dan dekomposisi dari senyawa yang tidak berikatan. Kemudian tahap kedua dekomposisi terjadi pada temperatur $320-450^{\circ} \mathrm{C}$ dengan degradasi yang cepat dan merupakan fenomena degradasi dari struktur crosslink polimer. Kemudian diatas temperature $450^{\circ} \mathrm{C}$ merupakan tahap terakhir dekomposisi atau dapat disebut juga degradasi material residu [6].

\section{KESIMPULAN}

Berdasarkan Penelitian Polimer Komposit Epoksi dengan variasi pengisi Cangkang Sawit 0\%, 20\%, 40\%, dan 60\% didapatkan kesimpulan bahwa Kekerasan polimer komposit epoksi meningkat dengan variasi pengisi serat cangkang sawit 20, 40, dan $60 \%$. Kekerasan tertinggi terdapat pada polimer komposit epoksi dengan pengisi serat cangkang sawit $60 \%$ sebesar 79 HD.Nilai Kekuatan tarik polimer epoksi mengalami penurunan dengan variasi pengisi serat cangkang sawit $20 \%$, $40 \%$, dan $60 \%$.Kekuatan tarik tertinggi terdapat pada polimer komposit epoksi serat cangkang sawit dan $20 \%$ sebesar 29,6 Mpa (301,83 kgf/cm²) sesuai dengan standar SNI 03-2105-2006. Stabilitas temperatur polimer epoksi meningkat dengan variasi pengisi serat cangkang sawit 20, 40, dan 60\%. Stabilitas temperatur tertinggi terdapat pada polimer komposit epoksi serat cangkang sawit $20 \%$. Berdasarkan kesimpulan yang telah diperoleh, polimer komposit epoksi serat cangkang sawit memiliki sifat mekanik yang baik dan ramah terhadap lingkungan, sehingga dapat digunakan sebagai kandidat pengganti papan partikel dan sesuai dengan SNI 03-2105-2006.

\section{DAFTAR PUSTAKA}

[1] Rasmawan, "Pemanfaatan Limbah Kelapa Sawit Pakan Ternak Sapi [Terhubung berkala]," http://library.usu.ac.id., 2009.

[2] Z. Nasution, "Characterization And Identification Of Functional Group Of Palm Shell Carbon By Using MethanoPyrolysis Method," 2013.

[3] B. D. Mistry, A Handbook of Spectroscopic Data Chemistry. Jaipur: Oxford Book Company, 2009.

[4] L. Fu Sheng, "Methanolisis and Hydrolisis of Polycarbonate Under Moderate Conditions," J. Polym. Enviromental, 2009.

[5] R. and Prasad, "Upgrading Biogas For Utilization as a Vehicle Fuel," Asian J. Energy Environ. As. J. Energy Env, pp. 387393, 2006.

M. M. Beyler, C. L., \& Hirschler, Thermal Decomposition of Polymers. New York, 2002. 